International Journal of Engineering \& Technology, $7(2)(2018) 555-558$
International Journal of Engineering \& Technology
SPC
Website: www.sciencepubco.com/index.php/IJET
Research paper

\title{
Designing Early Warning System for The Impact of Industrial Development Waste by Using pH Control System
}

\author{
Veronika Nugraheni Sri Lestari $^{1 *}$, Dwi Cahyono², Sri Susilowati ${ }^{3}$ \\ ${ }^{1}$ Economic and the Business Faculty, Dr.Soetomo, University, Surabaya, Indonesia \\ ${ }^{2}$ Engineering Faculty, Dr.Soetomo University, Surabaya, Indonesia \\ ${ }^{3}$ Economic and the Business Faculty, Dr.Soetomo, University, Surabaya, Indonesia \\ * Corresponding author E-mail: venugra@ unitomo.ac.id
}

This Paper is based on a presentation given by the authors at "Workshop of KO2PI" held from 19 January 2018 to 20 January 2018 in Indonesia.

\begin{abstract}
Environment is inseparable from human life. Human negligence in building industry without caring the impact on environment can damage the physical and biological environment slowly and indirectly. Therefore an effort to preserve the quality of environment, especially for the environment adjacent to the settlement, is necessary and can be performed in various ways including technology utilization. Technology develops rapidly and electronic devices have become one compulsory device to be owned. Wastewater is industrial waste should be controlled prior to passing surrounding environment to avoid pollution. One way to control it is controlling its $\mathrm{pH}$ of, this is performed by early warning on $\mathrm{pH}$ level. This paper focused on designing control device for industrial waste water $\mathrm{pH}$ that is able to inform an early when on concentration of industrial waste water under normal limit water.
\end{abstract}

Keywords: industry building, environment, microcontrollers, $\mathrm{pH}$ control.

\section{Introduction}

Environment is inseparable from human life. Environment is created when human lives in and vice versa. Environmental destruction by human has increased lately by the reasons of materials utilization to produce more material. Indirectly, this action will result in erosion of the environment and threaten human survival. Human negligence in building industry without caring the impact on environment can damage the physical and biological environment slowly and indirectly. Therefore an effort to preserve the quality of environment, especially for the environment adjacent to the settlement, is necessary and can be performed in various ways. This includes preparation of local development plans to projects implementation. For example, planning the use of spatial plans for regional economic development, determination of projects to be built and time management of project implementation. Such good planning of will be able to anticipate the bad effects on surrounding environment, reduce or even prevent environmental damage. From the elaborated problem, environmental management plan for the creation of a balance between human interest and environment should be made, one of which is through technology to control environment directly, that's way this research propose designing control system as early warning system for the impact industrial development waste by using $\mathrm{pH}$ control.

\section{Formulation of The Problems}

From the background delivered, formulation of the problems are as follows:
1. How to designing a control system as early warning system for the impact industrial development waste by using $\mathrm{pH}$ control?

2. What technological devices is able to control impact of industrial development on environment?

\section{Research Purposes}

The purpose of this research is to designing the control system that has ability to control and inform early on impact of industrial development on environment by making water $\mathrm{pH}$ controller device that connected to android-based communication device that inform the water $\mathrm{pH}$ control results to the society.

\section{Theatrical Basis and Hypotheses}

\subsection{Theatrical Basis}

\subsubsection{Industry in Indonesia}

Over the last 20 years Indonesia's economic development leads to industrialization. Nearly 30,000 industries operating in Indonesia have indicated improvement. The increasing number of industrialization increase pollution resulting from industrial production processes. Pollution of water, air, land and disposal of hazardous wastes and toxic (B3) is an issue that must be faced by communities living around industrial areas [1][2]. 


\subsubsection{Environmental Impact Assessment (EIA)}

Environmental Impact Assessment, which abbreviated to EIA, a reaction to environmental damage caused by increasing human activities. This reaction reaches extreme circumstances and cause stance against development and use of high technology. This creates image that the environmental movement is anti-development and anti-high technology and place environmental activists as opponent of development implementers and planners. Therefore many suspect that EIA is a tool to oppose and hinder development Development that does not sacrifice environment and/or damage environment is the development that takes into account the impact caused by the operation of such development. To ensure that a development can operate or feasible in terms of the environment, it is necessary to do the analysis or feasibility studies on the effects and consequences that arising from the implementation of activity/business plan.

EIA stands for environmental impact assessment. Government regulation no.27 of 1999 on environmental impact assessment states that IA is a study of major and significant impact on the decision making of a business and/ or planned activities on environment necessary for the decision-making process regarding business and / or activities.

Government Regulation No.27, 1999, article 1, paragraph 1 on EIA (Environmental Impact Assessment) is a study of major and significant impacts of a business and/or planned activities on environment necessary for decision making process.

\subsection{3. pH Sensor}

$\mathrm{pH}$ is the degree of acidity that used to express the degree of acidity or alkalinity of solution. It is defined as cologarithm of dissolved hydrogen ions $(\mathrm{H}+)$ activity. Hydrogen ion activity coefficients cannot be measured experimentally; hence the value is based on theoritical calculation. $\mathrm{pH}$ scale is not absolute scale This is relative to a set of standard solutions whose $\mathrm{pH}$ is determined on the basis of international agreements [3].

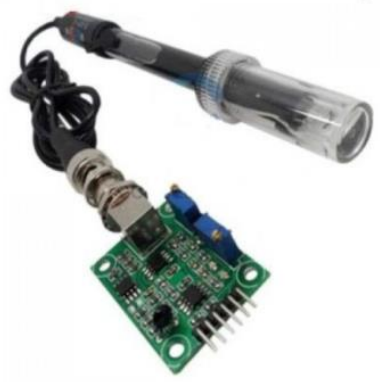

Fig. 1: pHsensor [3]

\subsubsection{Android}

Android is a Linux-based operating system mobile devices that includes an operating system, middleware and applications. Android provides an open platform for developers to create their applications [4][5].

Android is a new generation of mobile platform that provides an opportunity for developers to develop as expected. The underlying operating system of Android is licensed under the auspices of the GNU General Public License Version 2 (GPLv2), which is commonly known as Copy left [6]. The term copy left is license that any repairs by third parties must continue to fall under the terms.

Android distribution is under the Apache Software License (ASL / Apache2), which allows for second or subsequent distribution.
Android application developers are allowed to distribute their applications under the licensing scheme in any way they want.

\subsection{Hypothesis}

1. Development planning will have an impact on environment that is detrimental for the society.

2. Rapid development of technology will be able to help to overcome the impact of industrial development on environment.

\section{Research Methodology}

\subsection{Data Collection Method}

This study aims to produce data useful to provide an adequate understanding of the research object and problems faced. Therefore, the data obtained should be reliable, relevant, and can provide insight into actual situation. The method of data collection was conducted to collect data from the research object in the form of library research. This is carried out by collecting data from literature and books of reference and data that have relationship with the problems examined.

\subsection{Systems Development Method}

System development method used to control $\mathrm{pH}$ is System Development Life Cycle (SDLC) described in several stages [5][7][8]:

a. Determining Information Needs, this stage put anything decisive and determines information to users involved. The devices used to specify the information is to determine the sample and examine the raw data and interview.

b. Analyzing Information Needs, certain tools and techniques will help determine the needs. This involves the use of data flow diagrams to draw up a list of inputs, processes and outputs in the form of a structured chart. This is then developed into data dictionary which contains a whole list of items of data used in the system.

c. Designing Information Systems recommended, this is use information gathered earlier to achieve the design of logical information systems, designing procedures of data entry in such that the data entered into the information system is completely accurate and use e techniques and the design of particular layer to ensure the effectiveness of information systems input.

d. Developing and Documenting Programs, in this stage, initial software is developed. It needs some structured techniques for designing and documenting software includes plans and pseudo code.

e. Trial System, information must be tested before used to find out the problems before the system is implemented. This phase is performed routinely during the running of the information.

f. Implement and Evaluate System, this stage involves training for users to control the system. This evaluation is intended for the discussion of each stage, the main criteria to meet if the designated user actually use the system.

g. Identifying Problems, Opportunities and Goals, activity in this phase includes interviews with user management, concludes the knowledge gained, estimate the project scope, and document the results. The output of this stage is a flexible report contains definitions, problems and summary purposes 


\section{Discussion}

\subsection{Knowledge and understanding of industrial devel- opment impact}

It is mandatory for all of us to know the relationship between the type of environment. This is very important in order to tackle environmental issues in an integrated and complete way. Law enforcement officers also need to be given the knowledge as much as possible about the problem of environmental pollution.

The government must monitor industrial activities and disposal of wastes. Industry players must prevent environmental pollution by implementing clean technologies, installing pollution prevention, recycling process and most importantly, must performing waste processing to eliminate material contamination or at least minimize contamination of materials to the threshold.

In addition, it is necessary to study or conduct a study on the impact of specific industrial wastes (according to the type of industry) to the environment and to find methods or the appropriate technology for the prevention of the problem.

In addition to government and industry, society should be keen to respond to environmental problems caused by industrial activities. Society cannot fully submit this issue to the government and industry players. Addressing this issue is absolutely necessary, especially for people living around industrial areas. The impact of the discharge of industrial activities is very complex. Basically industrial waste will pollute the air, water, and soil. Dirty and polluted air will damage the olfactory and lungs.

Water pollution will damage aquatic and certainly will disturb the existence and availability of clean water sources. Pollution of soil, besides disturbing the soil fertility and anything that lives and grows on it will ultimately disrupt and contaminate the groundwater

\subsection{Control System Design}

The device consists of two modules of water $\mathrm{pH}$ sensor module connected with arduino [9][10] and communication modules transmitting sensor readings to be delivered in the form of android notifications.

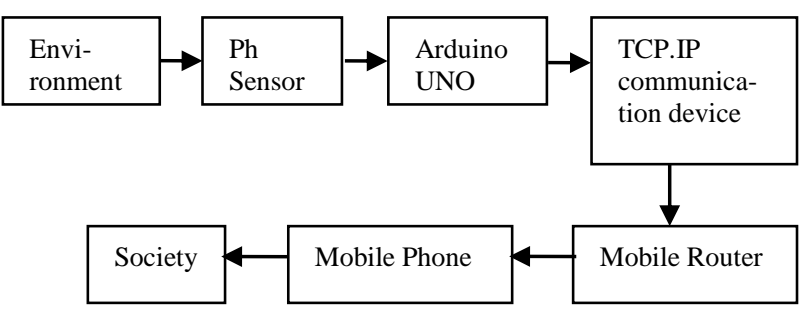

Fig. 2: pH Control Technology Architecture

$\mathrm{pH}$ sensor system sends data to arduino. If wastewater $\mathrm{pH}$ is $<7$ or $\mathrm{pH}>8.5$, arduino will transmit data to communication devices and it will be continued on the mobile router to transmit information on the mobile phone about the condition of polluted water.

\subsection{Process Model}

Process model from the system uses modeling applied by using UML (Unified Modeling Language). The following information will explain diagrams of UML to be applied to the system. Use Case Diagram

In the use case diagram, processes in the control system ph users using Arduino is explained

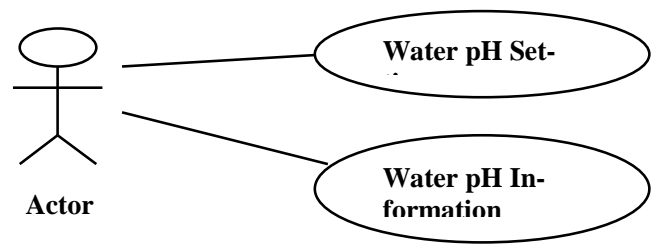

Fig. 3: Use Case Diagram System

\subsection{Formulation}

Data processing on $\mathrm{pH}$ level of water in water circulation system with $\mathrm{pH}$ control is explained. Data processing is used to determine the $\mathrm{pH}$ levels of industrial waste. From previous studies, grade or limit of the water ranging from normal or dangerous is obtained.

Table 1: Levels of water $\mathrm{pH}$

\begin{tabular}{cc}
\multicolumn{2}{c}{ Table 1: Levels of water $\mathrm{pH}$} \\
\hline Category & $\mathrm{pH}$ water \\
\hline Acid & $1-6$ \\
Normal & $6,5-8,5$ \\
Alkali & $8-14$ \\
\hline
\end{tabular}

Table 1 describes the $\mathrm{pH}$ level of the water status categories:

1. If water content is less than neutral value of 7 , the acid level in the pond is bad.

2. Neutral value in the pool ranges from $6,5-8.5$.

3. If water content in excesses neutral value of 7 the base levels is bad

\section{Result}

The system series describes the hardware workflow of water $\mathrm{pH}$ sensor system when receiving the signal then received by arduino to control the water pump. The entire water circulation with $\mathrm{pH}$ control is indicted in Figure 3

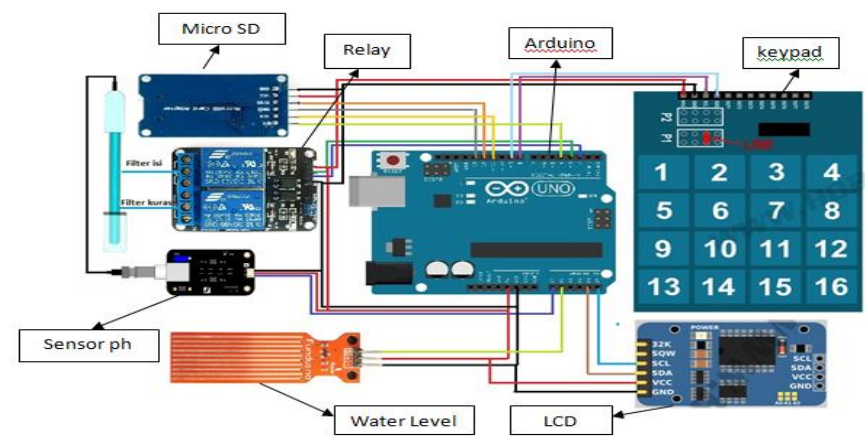

Fig. 4: Overall Design circuit of water $\mathrm{pH}$ sensor control system

In figure 4, the overall circuit of water circulation system with ph control using arduino is in hardware parts:

- Arduino uno

- $\mathrm{pH}$ sensor

- keypad

- LCD

- RTC (real time clock)

- Water level height sensor.

\section{Conclusions}

1. $\mathrm{pH}$ control system consist four important hardware part: Arduino uno, $\mathrm{pH}$ sensor, water level height sensor and TCP IP communication device. 
2. $\mathrm{pH}$ control system will provide early knowledge of the society of waste water that has certain $\mathrm{pH}$ levels.

3. Wastewater $\mathrm{pH}$ control system is able to provide accurate information related to the condition of the wastewater.

\section{Acknowledgement}

I would like to express our special thanks of gratitude to our principal (Dr. Soetomo University) and also RISTEK DIKTI for the precious opportunity to do this wonderful project on the topic of Early Warning System for the Impact of Industrial Development Waste By Using pH Control System, my roommates who have contributed to the research and shows us a lot of new wonderful thing I thank for. Secondly, I would also like to thank my family and friends who helped us a lot in finalizing this project within the limited time frame.

\section{References}

[1] C. R. Dempsey and E. T. Oppelt, "Incineration of hazardous waste: a critical review update," Air Waste, vol. 43, no. 1, pp 25-73, 1993.

[2] Z. Bian, J. Dong, S. Lei, H. Leng, S. Mu, and H. Wang, "The impact of disposal and treatment of coal mining wastes on environment and farmland," Environ. Geol., vol. 58, no. 3, pp. 625-634, 2009.

[3] DFRobot, "PH meter V1.1 SKU:SEN0161," 2014. [Online]. Available:

https://www.dfrobot.com/wiki/index.php/PH_meter_V1.1_SKU: SEN0161. [Accessed: 25-Mar-2014].

[4] S. A. Latif, SIG Fasilitas Umum di Bojonegoro Berbasis Android. Surabaya: Universitas Dr. Soetomo, 2013.

[5] A. S. Ahmar and A. Rahman, "Development of teaching material using an Android," Glob. J. Eng. Educ., vol. 19, no. 1, 2017.

[6] G. N. U. G. P. License, "The GNU Operating system," URL http//www. gnu. org/licenses/gpl. html (дата обращения 21.03. 10), 2008.

[7] A. S. Ahmar, Rusli, and A. Rahman, "Steps in Designing Queue and Interview Process using Information System: A Case of Reregistration of New Students in Universitas Negeri Makassar," Asian J. Technol. Manag., vol. 9, no. 1, pp. 52-57, 2016.

[8] A. S. Ahmar, A. Rahman, A. N. M. Arifin, and A. A. Ahmar, "Predicting movement of stock of ' $\mathrm{Y}$ ' using sutte indicator," Cogent Econ. Financ., vol. 5, no. 1, 2017.

[9] M. N. Rao, "Temperature based fan speed control and observing utilizing arduino," Int. J. Eng. Technol., vol. 7, no. 1.1, pp. 685688, 2017.

[10] P. S. S. Teja, M. Vineel, G. Manisha, and S. Satyanarayana, "Automated irrigation system using sensors and node micro controller unit," Int. J. Eng. Technol., vol. 7, no. 1.1, pp. 240242, 2017. 